\title{
Allergic effects of the residual monomer used in denture base acrylic resins
}

\author{
Haroon Rashid ${ }^{1}$, Zeeshan Sheikh ${ }^{2}$, Fahim Vohra ${ }^{3}$
}

Correspondence: Dr. Haroon Rashid

Email: drh.rashid@hotmail.com

\author{
'Department of Prosthodontics, College of Dentistry, \\ Ziauddin University, Karachi, Pakistan, \\ ${ }^{2}$ Matrix Dynamics Group, Faculty of Dentistry, \\ University of Toronto, Ontario, Canada, \\ ${ }^{3}$ Department of Prosthodontics, College of Dentistry, \\ King Saud University, Riyadh, Saudi Arabia
}

\section{ABSTRACT}

Denture base resins are extensively used in dentistry for a variety of purposes. These materials can be classified as chemical, heat, light, and microwave polymerization materials depending upon the factor which starts the polymerization reaction. Their applications include use during denture base construction, relining existing dentures, and for fabrication of orthodontic removable appliances. There have been increased concerns regarding the safe clinical application of these materials as their biodegradation in the oral environment leads to harmful effects. Along with local side effects, the materials have certain occupational hazards, and numerous studies can be found in the literature mentioning those. The purpose of this article is to outline the cytotoxic consequences of denture base acrylic resins and clinical recommendations for their use.

Key words: Denture base allergy, denture base resins, residual monomer

\section{INTRODUCTION}

The use of acrylic based resins in dentistry has become very frequent, and these materials offer properties and characteristics due to which they can be used for many purposes. Common uses of these materials include the fabrication of denture bases, orthodontic removable appliances, temporary crowns, and denture relining. ${ }^{[1-4]}$ The acrylic resin bases are used for removable partial or complete dentures and also for implant supported removable dentures. ${ }^{[5]}$ Orthodontic appliances made up of acrylic resin serve many purposes including space maintenance and arch expansion. ${ }^{[6]}$ The use of acrylic temporary crowns is important during crown and bridge fabrication processes, and these provisional restorations are usually placed after tooth preparation using temporary luting cement. ${ }^{[7]}$ Acrylic based soft and the hard relining process is very useful in removable prosthodontics which helps in improving denture's retention, stability, and support. ${ }^{[8]}$ Soft reliners are also useful for recording neutral zone impressions of completely edentulous arches. ${ }^{[9,10]}$ The use of acrylic resins for copings in restorative dentistry has also been described, however, this use in modern dentistry is not widely documented. ${ }^{[11]}$

Undesirable effects caused by denture base resins have been widely documented in the literature. ${ }^{[12-16]}$ The most common and frequently reported a problem with the patients having allergic reactions to denture base acrylic resin is mouth soreness and burning sensation. Areas presenting with burning sensation include the palate, tongue, oral mucosa, and the oropharynx..$^{[17,18]}$ Allergic tests carried on the skin of patients has also confirmed that the denture base acrylic resin is responsible for allergic reactions. ${ }^{[19-21]}$ Thus, whenever a denture wearer presents with signs and symptoms outlined above, a possibility

This is an open access article distributed under the terms of the Creative Commons Attribution-NonCommercial-ShareAlike 3.0 License, which allows others to remix, tweak, and build upon the work non-commercially, as long as the author is credited and the new creations are licensed under the identical terms.

For reprints contact: reprints@medknow.com

How to cite this article: Rashid H, Sheikh Z, Vohra F. Allergic effects of the residual monomer used in denture base acrylic resins. Eur J Dent 2015;9:614-9.

DOI: $10.4103 / 1305-7456.172621$ 
of allergic reaction must always be considered, and thorough investigation carried out to achieve an accurate diagnosis. For the immediate and delayed type of hypersensitivity reactions, patch testing, blood tests, or allergen specific IgE tests can be carried out. ${ }^{[22,23]}$

The cytotoxic effects caused by denture base acrylic resins are mainly caused by the substances leaching out from these resins. The main substance which is leached out by the process of diffusion from these materials is the unreacted residual monomer. ${ }^{[24-26]}$ Constant contact of saliva with the material cause's expansion of the openings present between the polymer chains causing the unreacted monomer to diffuse out. Thus, the substances which are leached out from the denture bases into the saliva are transferred to the oral structures causing adverse allergic reactions. ${ }^{[3,27,28]}$

It is worth emphasizing that steps must be undertaken to ensure that dental practitioners and students are aware of these adverse effects. The purpose of the current article is to outline the cytotoxic consequences of denture base acrylic resin, clinical recommendations for their use and to review previous similar published literature.

\section{CLASSIFICATION OF DENTURE BASE RESINS}

Acrylic denture base polymers are mainly used for the construction of denture bases in partially or completely edentulous arches. A denture base is that portion of a denture which rests over the soft tissues in the oral cavity. McCabe and Walls ${ }^{[29]}$ classified denture base polymers into five types. Table 1 outlines the classification of denture base polymers. Table 2 outlines the main constituents of powder and liquid of denture base polymers where activator ( $\mathrm{N} \mathrm{N}^{\prime}$-dimethyl-p-toluidine) being only present in self-sure/auto-polymerized denture base resins.

It has been reported that self-cured/auto-polymerized acrylic resins leach out higher quantities of residual monomer than heat-cured denture base resins. ${ }^{[29-32]}$ Baker et al., ${ }^{[33]}$ during their investigation found greater quantities of methyl methacrylate (MMA) in saliva of the individuals who were wearing dentures made up of self-cured/auto-polymerized denture base resins. Kedjarune et al., ${ }^{[34]}$ stated that the quantity of the residual monomer was actually dependent

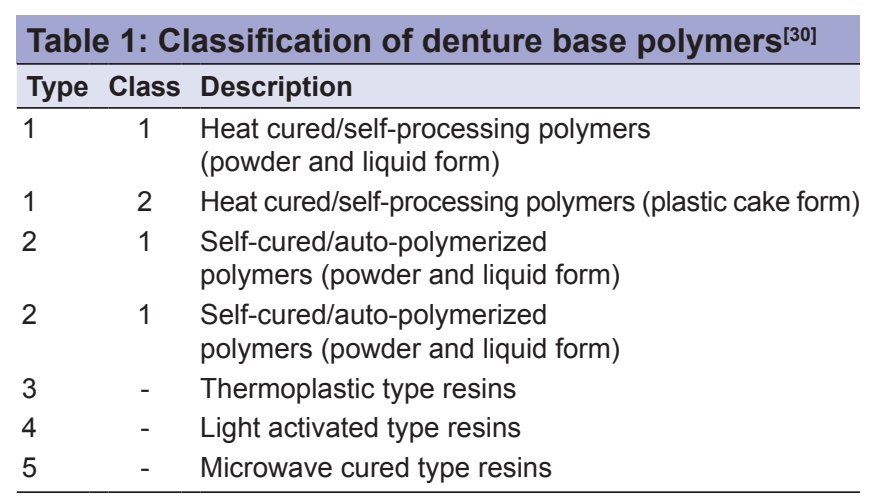

\begin{tabular}{ll}
$\begin{array}{l}\text { Table 2: Composition of acrylic denture base } \\
\text { materials }{ }^{[29]}\end{array}$ \\
\hline Component & Constituents \\
\hline $\begin{array}{l}\text { Powder } \\
\text { Polymer }\end{array}$ & Polymethylmethacrylate beads \\
Initiator & A peroxide such as a benzoyl peroxide \\
Pigments & Salts of cadmium or iron or organic dyes \\
Liquid & Methyl methacrylate \\
Monomer & Ethylene glycol dimethacrylate \\
Cross-linking agent & Hydroquinone \\
Inhibitor & $N N^{\prime}$-dimethyl- $p$-toluidine \\
Activator &
\end{tabular}

upon the method of polymerization and the powder liquid $(\mathrm{P} / \mathrm{L})$ ratio used during mixing of the material. They recommended that it must be ensured that the amount of residual monomer is reduced before insertion of the dentures and suggested that the practitioners recommend to their patients that newly made dentures are not to be worn overnight so as to avoid mucosal irritation caused due to leachable residual monomer molecules.

\section{POLYMERIZATION REACTION AND THE MONOMER CONTENT}

The polymerization reaction in denture base resins is an addition reaction that involves the activation of the initiator. It is usually through heat polymerization (heat-curing), auto-polymerization (self-curing), and light polymerization. ${ }^{[34-38]}$ The polymerization reaction (the curing process) results in the conversion of MMA into poly-MMA during which the monomer molecules are converted into polymers. During this process, not all the monomer molecules are converted and thus, some unreacted residual monomers remain unpolymerized. ${ }^{[29]}$ The unreacted monomer may leach out into the saliva which actually causes the cytotoxic effects in the oral cavity. ${ }^{[39,40]}$ The greater the quantity of the unreacted monomer, higher will be the deleterious effects. 
One of the important factors that must be considered during manipulation of denture base resins is the $\mathrm{P} / \mathrm{L}$ ratio of the materials. When Jorge et al., ${ }^{[41]}$ carried out a study investigating the $\mathrm{P} / \mathrm{L}$ ratios of these resins during manipulation, they found out that when resins were prepared in the laboratory using higher levels of the polymer (contained in the powder) content that is, to a ratio of 5:3, lower quantities of the residual monomer were found. Lesser the amount of residual monomer, lesser would be the cytotoxic effects. ${ }^{[34]}$

The polymerization temperature is another factor that plays a vital role and is responsible for different degrees of cytotoxic effects. When polymerization time is extended, the amount of residual unreacted monomer is reduced significantly and thus, the chances of cytotoxic effects are reduced. It has been recommended that a $7 \mathrm{~h}$ incubation in water at $70^{\circ} \mathrm{C}$ followed by a $1-\mathrm{h}$ incubation in water at $100^{\circ} \mathrm{C}$ causes the maximum conversion of the monomer. ${ }^{[42]}$ It has been recommended that boiling during polymerization stage should be carried out for at least 30 min at maximum temperatures and that the heat-cured denture bases should be stored in water for 1-2 days before being delivered to the patients. This is expected to reduce the cytotoxic effects caused due to residual monomer to a significant extent. ${ }^{[40]}$ Self-cured denture bases which are additionally polymerized in water at $60^{\circ} \mathrm{C}$ and are kept in water at room temperature for a period of 1-day show significantly decreased amounts of residual monomer content. ${ }^{[2]}$

Among various laboratory methods used to carry out polymerization of denture base acrylic resins, it is well understood that heat-cured acrylic resins have shown to produce less cytotoxic effects, ${ }^{[43]}$ while the greatest deleterious effects have been shown to be produced by self-cured acrylics. ${ }^{[44]}$ When cytotoxic effects of microwave cured acrylic resins were tested, it was shown that 20 min of polymerization carried out using microwave irradiation resulted in residual monomer content which was significantly reduced as compared to the monomer content found using other polymerization methods. ${ }^{[45,46]}$ This reduction in the monomer content after using the microwave method of polymerization could play a vital role in the reduction of the hazardous effects of the material. $^{[47]}$

Optimum polymerization conditions must be identified and extended time for polymerization must be used to reduce the cytotoxic effects. Dentures fabricated using self-cured acrylic resins should be avoided, and immersion of newly made dentures in water should be recommended. However, regardless of the curing conditions, the unreacted residual monomer in denture base acrylic resins is inevitable and could be a source of the problem for both clinicians and the patients. ${ }^{[48,49]}$

\section{THE HARMFUL EFFECTS}

Reports of allergic effects caused among professionals due to the use of dental materials are becoming increasingly common and patch testing has proven to be a reliable and easy way to detect these potential reactions. ${ }^{[19]}$ Clinical practice in prosthodontics involves the fabrication of implant-supported dentures, conventional fixed and removable partial dentures. Since the acrylic resin is the main constituent of these prostheses, allergic reactions may also be encountered in patients. As mentioned previously, unreacted MMA monomer may leach out into the oral cavity, and results in toxic effects and allergic reactions, especially, if the prosthesis is undercured. Significant damage at the cellular level involving cell membrane, mitochondria, and lymphocytes has previously been reported in the literature. ${ }^{[50,51]}$

During manipulation of acrylic resins, vaporization of the MMA monomer occurs, and this may causes harmful effects due to inhalation which can potentially irritate the lung tissues and can also affect the central nervous system (CNS). ${ }^{[52]}$ A study which involved exposing rats to MMA vapors showed that there were histological manifestations clearly present such as edema, emphysema, and even collapse of the lungs. ${ }^{[53]}$ Therefore, it must be stressed that the dental technicians who manipulate acrylic resin must work in an environment which is thoroughly ventilated so that harmful effects including dyspnea, cough, and triggering of asthma could be minimized and ideally avoided. ${ }^{[54,55]}$ MMA can also penetrate the skin and it is also recommended that the resin during mixing is not held with bare hands since direct neurotoxic effects may be caused. Myelinated nerve functions have shown to be affected if MMA is absorbed directly via the skin and may lead to neuropathy. ${ }^{[56]}$

Contact allergy is a condition seen in the denture wearers which is a result of delayed hypersensitivity reaction. As mentioned previously, the effects of self-cured acrylic resins is more as compared to 
the heat-cured ones, however, it must be stressed that the symptoms of burning mouth and/or soreness could be occurring due to a variety of other factors including ill-fitting dentures and poor oral hygiene. ${ }^{[57-59]}$ The presence of saliva in the oral cavity provides the essential defensive barrier by diluting the potential harmful antigens before their penetration into the oral mucosa. The effect of the penetrated irritants is also reduced due to the high vascular nature of the oral mucosa. However, this will largely depend on the concentration of the residual monomer. ${ }^{[33,34,60,61]}$ The chairside relining procedure involves the application of resin based relining materials. They are usually hard and soft reliners and care should be exercised during their use as the residual monomer is readily leached out immediately and could be a source of irritation to the oral mucosa. The immersion of auto-polymerized resins in water before insertion into the patient's mouth is particularly important. ${ }^{[43,44]}$

The monomer used during manipulation of acrylic resins may cause direct effects on the skin of dental technicians and students in the laboratories. These effects are usually dependent on the time of exposure and are mostly occupational. ${ }^{[62]}$ It must be mentioned that the gloves worn for cross infection control have no effect over contamination by the monomers. The monomer penetrates vinyl and latex gloves and could become a source of irritation to the skin of clinicians and the technicians. ${ }^{[63]}$ Ingestion of MMA (by mistake or deliberately) may also lead to systemic side effects affecting the gastrointestinal tract and may cause CNS effects that is, sleepiness, dizziness, headaches, and blurred vision. ${ }^{[64,65]}$

\section{RECOMMENDATIONS FOR USE}

Users must be made aware that denture base resins and other materials used in dentistry not only effect the environment but may also cause local and systemic side effects. The authors would like to recommend the following measures so that the deleterious effects of denture base resins can be minimized:

a) It is highly recommended that the areas where denture base resin materials are being used are thoroughly ventilated so that effects caused due to vaporization of the residual monomer could be reduced

b) The use of impermeable gloves is recommended along with the use of aprons and protective eyewear c) The material must be stored in tightly sealed containers

d) In case of exposure, the site must be thoroughly washed with water especially if the contact has been made with the eye. Contact lenses should be removed immediately and washed thoroughly

e) Move to an area with fresh air and loosen up tight clothing to facilitate breathing in case contact was made, and ventilation was not appropriate. If there is a spill, clean the area thoroughly using appropriate cleaning agents

f) Proper curing techniques must be applied, and the use of vacuum mixing is recommended

g) In case of any symptom appearing and if they persist, immediately seek medical advice.

\section{CONCLUSION}

Whenever, a patient wearing an acrylic prosthesis complains for allergic reaction or chemical irritation, the possibility of these symptoms caused by denture base materials must be considered. These materials have good properties and offer reasonable esthetics, however; they may cause toxic side effects in some individuals. Regardless of the curing technique used, the presence of unreacted residual monomer in denture base acrylic resins is inevitable and could be a source of problem for both clinicians and the patients and techniques must be applied in laboratory and clinical settings to reduce the exposure as much as possible. In addition, emphasis must be given to raise awareness among the dental students and technicians about the possible hazardous side effects caused by these materials.

\section{Financial support and sponsorship}

Nil.

\section{Conflicts of interest}

There are no conflicts of interest.

\section{REFERENCES}

1. León BL, Del Bel Cury AA, Rodrigues Garcia RC. Loss of residual monomer from resilient lining materials processed by different methods. Rev Odontol Ciênc 2008;23:215-9.

2. Bayraktar G, Guvener B, Bural C, Uresin Y. Influence of polymerization method, curing process, and length of time of storage in water on the residual methyl methacrylate content in dental acrylic resins. J Biomed Mater Res B Appl Biomater 2006;76:340-5.

3. Urban VM, Machado AL, Vergani CE, Giampaolo ET, Pavarina AC, de Almeida FG, et al. Effect of water-bath post-polymerization on the mechanical properties, degree of conversion, and leaching of residual compounds of hard chairside reline resins. Dent Mater 2009;25:662-71.

4. Nironen P. Some possible uses for acrylic resins in dentistry. Odontol Tidskr 1950;58:118-25. 
5. Eichhold WA, Woelfel JB. Denture base acrylic resins: Friend or foe? Compendium 1990;11:720-5.

6. Faltermeier A, Rosentritt M, Müssig D. Acrylic removable appliances: Comparative evaluation of different postpolymerization methods. Am J Orthod Dentofacial Orthop 2007;131:301.e16-22.

7. Luo Y, Wang W, Yang Z. Clinical evaluation of two temporary restoration materials: Composite and self-cured acrylic resin. Hua Xi Kou Qiang Yi Xue Za Zhi 2003;21:222-5.

8. Tanoue N, Matsuda Y, Yanagida H, Matsumura H, Sawase T. Factors affecting the bond strength of denture base and reline acrylic resins to base metal materials. J Appl Oral Sci 2013;21:320-6.

9. Makzoumé JE. Morphologic comparison of two neutral zone impression techniques: A pilot study. J Prosthet Dent 2004;92:563-8.

10. Devaki VN, Manonmani P, Balu K, Aravind RJ. Clinical management of highly resorbed mandibular ridge without fibrous tissue. J Pharm Bioallied Sci 2012;4 Suppl 2:S149-52.

11. Crispin B. Acrylic resin copings: An adjunct to fixed restorative dentistry. J Prosthet Dent 1978;39:632-6.

12. Giunta JL, Grauer I, Zablotsky N. Allergic contact stomatitis caused by acrylic resin. J Prosthet Dent 1979;42:188-90.

13. Weaver RE, Goebel WM. Reactions to acrylic resin dental prostheses. J Prosthet Dent 1980;43:138-42.

14. Ali A, Bates JF, Reynolds AJ, Walker DM. The burning mouth sensation related to the wearing of acrylic dentures: An investigation. Br Dent J 1986;161:444-7.

15. Koutis D, Freeman S. Allergic contact stomatitis caused by acrylic monomer in a denture. Australas J Dermatol 2001;42:203-6.

16. Gonçalves TS, Morganti MA, Campos LC, Rizzatto SM, Menezes LM. Allergy to auto-polymerized acrylic resin in an orthodontic patient. Am J Orthod Dentofacial Orthop 2006;129:431-5.

17. Cibirka RM, Nelson SK, Lefebvre CA. Burning mouth syndrome: A review of etiologies. J Prosthet Dent 1997;78:93-7.

18. Van Joost T, van Ulsen J, van Loon LA. Contact allergy to denture materials in the burning mouth syndrome. Contact Dermatitis 1988;18:97-9.

19. Rai R, Dinakar D, Kurian SS, Bindoo YA. Investigation of contact allergy to dental materials by patch testing. Indian Dermatol Online J 2014;5:282-6.

20. Gosavi SS, Gosavi SY, Alla RK. Local and systemic effects of unpolymerised monomers. Dent Res J (Isfahan) 2010;7:82-7.

21. Fernström AI, Oquist G. Location of the allergenic monomer in warm-polymerized acrylic dentures. Part II: Experiments aimed at establishing guidelines for production of acrylic dentures suited for patients allergic to acrylic monomer and complementary investigations. Swed Dent J 1980;4:253-60.

22. Gawkrodger DJ. Investigation of reactions to dental materials. Br J Dermatol 2005;153:479-85.

23. Usmani N, Wilkinson SM. Allergic skin disease: Investigation of both immediate- and delayed-type hypersensitivity is essential. Clin Exp Allergy 2007;37:1541-6.

24. Chaves CA, Machado AL, Vergani CE, de Souza RF, Giampaolo ET. Cytotoxicity of denture base and hard chairside reline materials: A systematic review. J Prosthet Dent 2012;107:114-27.

25. Iça RB, Öztürk F, Ates B, Malkoc MA, Kelestemur Ü. Level of residual monomer released from orthodontic acrylic materials. Angle Orthod 2014;84:862-7.

26. Nik TH, Shahroudi AS, Eraghihzadeh Z, Aghajani F. Comparison of residual monomer loss from cold-cure orthodontic acrylic resins processed by different polymerization techniques. J Orthod 2014;41:30-7.

27. Gautam R, Singh RD, Sharma VP, Siddhartha R, Chand P, Kumar R. Biocompatibility of polymethylmethacrylate resins used in dentistry. J Biomed Mater Res B Appl Biomater 2012;100:1444-50.

28. Kopperud HM, Kleven IS, Wellendorf H. Identification and quantification of leachable substances from polymer-based orthodontic base-plate materials. Eur J Orthod 2011;33:26-31.

29. McCabe JF, Walls A. Applied Dental Materials. $9^{\text {th }}$ ed. Oxford, UK: Willey-Blackwell; 2013. p. 112-3.

30. Anderson JN. Applied Dental Materials. $5^{\text {th }}$ ed. Oxford: Blackwell Scientific Publications; 1976. p. 245-70.

31. Douglas WH, Bates JF. The determination of residual monomer in polymethyl-methacrylate denture base resins. J Mater Sci 1978;13:2600-4.

32. Pfeiffer P, Rosenbauer EU. Residual methyl methacrylate monomer, water sorption, and water solubility of hypoallergenic denture base materials. J Prosthet Dent 2004;92:72-8.

33. Baker S, Brooks SC, Walker DM. The release of residual monomeric methyl methacrylate from acrylic appliances in the human mouth: An assay for monomer in saliva. J Dent Res 1988;67:1295-9.

34. Kedjarune U, Charoenworaluk N, Koontongkaew S. Release of methyl methacrylate from heat-cured and autopolymerized resins: Cytotoxicity testing related to residual monomer. Aust Dent J 1999;44:25-30.

35. Goldibi F, Asghari G. The level of residual monomer in acrylic denture base materials. Res J Biol Sci 2009;4:244-9.

36. Celebi N, Yuzugullu B, Canay S, Yucel U. Effect of polymerization methods on the residual monomer level of acrylic resin denture base polymers. Polym Adv Technol 2008;19:201-6.

37. Bartoloni JA, Murchison DF, Wofford DT, Sarkar NK. Degree of conversion in denture base materials for varied polymerization techniques. J Oral Rehabil 2000;27:488-93.

38. Ogle RE, Sorensen SE, Lewis EA. A new visible light-cured resin system applied to removable prosthodontics. J Prosthet Dent 1986;56:497-506

39. Singh RD, Gautam R, Siddhartha R, Singh BP, Chand P, Sharma VP, et al. High performance liquid chromatographic determination of residual monomer released from heat-cured acrylic resin. An in vivo study. J Prosthodont 2013;22:358-61.

40. Bural C, Aktas E, Deniz G, Unlucerci Y, Bayraktar G. Effect of leaching residual methyl methacrylate concentrations on in vitro cytotoxicity of heat polymerized denture base acrylic resin processed with different polymerization cycles. J Appl Oral Sci 2011;19:306-12.

41. Jorge JH, Giampaolo ET, Machado AL, Vergani CE. Cytotoxicity of denture base acrylic resins: A literature review. J Prosthet Dent 2003;90:190-3.

42. Harrison A, Huggett R. Effect of the curing cycle on residual monomer levels of acrylic resin denture base polymers. J Dent 1992;20:370-4.

43. Ata SO, Yavuzyilmaz H. In vitro comparison of the cytotoxicity of acetal resin, heat-polymerized resin, and auto-polymerized resin as denture base materials. J Biomed Mater Res B Appl Biomater 2009;91:905-9.

44. Sheridan PJ, Koka S, Ewoldsen NO, Lefebvre CA, Lavin MT Cytotoxicity of denture base resins. Int J Prosthodont 1997;10:73-7.

45. Cimpan MR, Cressey LI, Skaug N, Halstensen A, Lie SA, Gjertsen BT, et al. Patterns of cell death induced by eluates from denture base acrylic resins in U-937 human monoblastoid cells. Eur J Oral Sci 2000;108:59-69.

46. Azzarri MJ, Cortizo MS, Alessandrini JL. Effect of the curing conditions on the properties of an acrylic denture base resin microwavepolymerised. J Dent 2003;31:463-8.

47. Blagojevic V, Murphy VM. Microwave polymerization of denture base materials. A comparative study. J Oral Rehabil 1999;26:804-8.

48. Lung CY, Darvell BW. Minimization of the inevitable residual monomer in denture base acrylic. Dent Mater 2005;21:1119-28.

49. Lung CY, Darvell BW. Methyl methacrylate monomer-polymer equilibrium in solid polymer. Dent Mater 2007;23:88-94.

50. Bereznowski Z. Effect of methyl methacrylate on mitochondrial function and structure. Int J Biochem 1994;26:1119-27.

51. Drozdz K, Wysokinski D, Krupa R, Wozniak K. Bisphenol A-glycidyl methacrylate induces a broad spectrum of DNA damage in human lymphocytes. Arch Toxicol 2011;85:1453-61.

52. Walther UI, Walther SC, Liebl B, Reichl FX, Kehe K, Nilius M, et al. Cytotoxicity of ingredients of various dental materials and related compounds in L2- and A549 cells. J Biomed Mater Res 2002;63:643-9.

53. Sokmen S, Oktemer M. Histopathological examinations of rat lungs that exposed to low concentration of methyl methacrylate monomer vapor. J Hacettepe Factors Dent 1988;12:1-4.

54. Lozewicz S, Davies RJ. Inflammatory cells in allergic rhinitis. Respir Med 1991;85:259-61.

55. Aalto-Korte K, Alanko K, Kuuliala O, Jolanki R. Methacrylate and acrylate allergy in dental personnel. Contact Dermatitis 2007;57:324-30.

56. Böhling HG, Borchard U, Drouin H. Monomeric methylmethacrylate (MMA) acts on the desheathed myelinated nerve and on the node of Ranvier. Arch Toxicol 1977;38:307-14.

57. Lamey PJ, Lewis MA. Oral medicine in practice: Burning mouth syndrome. Br Dent J 1989;167:197-200.

58. Crissey JT. Stomatitis, dermatitis, and denture materials. Arch 
Dermatol 1965;92:45-8.

59. Bauer A, Wollina U. Denture-induced local and systemic reactions to acrylate. Allergy 1998;53:722-3.

60. Van 't Hof W, Veerman EC, Nieuw Amerongen AV, Ligtenberg AJ. Antimicrobial defense systems in saliva. Monogr Oral Sci 2014;24:40-51.

61. Tosti A, Piraccini BM, Peluso AM. Contact and irritant stomatitis. Semin Cutan Med Surg 1997;16:314-9.

62. Kanerva L. Cross-reactions of multifunctional methacrylates and acrylates. Acta Odontol Scand 2001;59:320-9.

63. Nakamura M, Oshima H, Hashimoto Y. Monomer permeability of disposable dental gloves. J Prosthet Dent 2003;90:81-5.

64. Tansy MF, Martin JS, Benhaim S, Landin WE, Kendall FM. GI motor inhibition associated with acute exposure to methyl methacrylate vapor. J Pharm Sci 1977;66:613-9.
65. Anderson SE, Meade BJ. Potential health effects associated with dermal exposure to occupational chemicals. Environ Health Insights 2014;8 Suppl 1:51-62.

\begin{tabular}{|l|l|}
\hline \multicolumn{2}{|c|}{ Access this article online } \\
\hline Quick Response Code: \\
\hline
\end{tabular}

